\title{
Analisis Negara-Negara Terjangkit Virus Covid-19 berdasarkan Kelompok Pendapatan dan Negara Tropis di Benua Asia Menggunakan Multiple Classification Analysis
}

Aprilia Lutviana Dewi

Politeknik Statistika STIS, 211709566@stis.ac.id

Nur Aini

Politeknik Statistika STIS

Fajar Rakha Pratama

Politeknik Statistika STIS

Risni Julaeni Yuhan

Politeknik Statistika STIS

\begin{abstract}
ABSTRAK, Virus Corona atau severe acute respiratory syndrome coronavirus 2 (SARS-CoV-2) saat ini tengah menjadi pandemi global, yang dikenal dengan sebutan COVID-19. Negara - negara yang lebih dulu terjangkit COVID-19 adalah negara-negara yang masuk dalam kelompok pendapatan tinggi. Padahal negara berpendapatan tinggi lebih mudah untuk memenuhi kebutuhan nutrisi dan kesehatannya dibandingkan dengan negara berpendapatan rendah. Selain itu, kondisi iklim juga mungkin mempengaruhi penyebaran virus. Negara dengan iklim tropis merupakan negara yang lebih lambat terjangkit dibandingkan dengan negara yang tidak beriklim tropis, sehingga diasumsikan virus ini lebih susah menyebar di iklim tropis. Dalam penelitian ini dilihat hubungan antara jumlah kasus positif COVID-19 dengan kelompok pendapatan serta iklim di negara yang terkena corona di benua Asia menggunakan MCA (Multiple Classification Analysis). Hasil penelitian ini membuktikan bahwa kasus positif COVID-19 di Benua Asia lebih banyak terjadi di negara non-tropis dibandingkan negara tropis. Berdasarkan kelompok pendapatan, semakin tinggi kelompok pendapatan pada negara tropis di Benua Asia maka jumlah kasus positif COVID-19 cenderung meningkat. Hal ini juga terjadi pada negara non-tropis di Benua Asia.
\end{abstract}

Kata Kunci: COVID-19, Multiple Classification Analysis, Kelompok Pendapatan, Negara Tropis

\section{PENDAHULUAN}

Virus Corona atau severe acute respiratory syndrome coronavirus 2 (SARS$\mathrm{CoV}-2$ ) adalah virus yang menyerang sistem pernapasan. Virus Corona bisa mengakibatkan gangguan pada sistem pernapasan, pneumonia akut, sampai kematian. Virus ini merupakan jenis baru dari coronavirus yang menular ke manusia. Virus ini bisa menyerang siapa saja, baik bayi, anak-anak, orang dewasa, lansia, Penyakit karena infeksi virus ini disebut COVID-19.

Siapapun dapat terinfeksi virus corona. Akan tetapi, bayi dan anak kecil, serta orang dengan kekebalan tubuh yang lemah lebih rentan terhadap serangan virus ini. Virus ini lebih mudah menyerang orang dengan tingkat imunitas yang rendah. Negara - negara yang lebih dulu terjangkit COVID-19 adalah negara-negara yang termasuk berpendapatan tinggi (HungerMap, 2020). Padahal negara berpendapatan tinggi lebih mudah untuk memenuhi kebutuhan nutrisi dan kesehatannya dibandingkan dengan negara berpendapatan rendah. Negara berpendapatan tinggi biasanya memiliki fasilitas kesehatan yang memadai sehingga orang-orang di negara berpendapatan tinggi seharusnya lebih sehat dan memiliki daya imunitas yang lebih tinggi.

Selain itu, kondisi iklim juga mungkin mempengaruhi penyebaran virus corona. Menurut BMKG iklim torpis mampu menghambat pertumbuhan virus corona. Analisis yang dilakukan oleh BMKG bersama 11 doktor di Bidang Meteorologi, Klimatologi dan Matematika menunjukkan adanya indikasi pengaruh cuaca dan iklim dalam penyebaran wabah COVID-19. Virus COVID-19 berasal dari Kota Wuhan, Tiongkok, yang beriklim subtropis. Virus ini kemudian menyebar ke negaranegara yang beriklim sub tropis, sedang, dan dingin seperti Iran, Jepang dan Korea Selatan. Negara dengan iklim tropis merupakan negara yang baru terkena virus ini, lebih lambat terkena virus corona dibandingkan dengan negara yang tidak beriklim tropis, sehingga diasumsikan virus 
corona lebih susah menyebar di negara dengan iklim tropis.

Dalam penelitian ini, akan dilihat hubungan jumlah kasus COVID-19 dengan tingkat pendapatan serta iklim di negara yang terjangkit corona di benua Asia menggunakan MCA (Multiple Classification Analysis). Metode MCA digunakan ketika variabel bebas berupa kategorik atau berbentuk dummy variabel sedangkan variabel tidak bebasnya berupa variabel interval atau rasio. Dalam penelitian ini, variabel tidak bebasnya adalah jumlah kasus positif di setiap negara terjangkit COVID-19 di benua Asia (per 11 April 2020). Sedangkan variabel bebasnya adalah kelompok pendapatan negara $\left(\mathrm{X}_{1}\right)$ dan kelompok negara tropis/bukan $\left(\mathrm{X}_{2}\right)$.

\section{TINJAUAN PUSTAKA}

MULTIPLE CLASSIFICATION ANALYSIS

Multiple Classification Analysis (MCA) adalah analisis dengan variabel tak bebas adalah variabel kuantitatif dan variabel bebas adalah variabel kategori yang dijelaskan sebagai dummy variable [4]. MCA merupakan sebuah teknik untuk menduga hubungan antara beberapa variabel bebas dan satu variabel tak bebas serta menentukan pengaruh dari setiap variabel bebas terhadap variabel tak bebas baik dengan mempertimbangkan pengaruh variabel bebas lainnya (adjusted) ataupun tidak serta untuk mengetahui pengaruh seluruh variabel bebas secara bersama sama terhadap variasi variabel tak bebas. MCA didesain untuk variabel bebas yang diukur dalam skala kategorik, sedangkan variabel tidak bebasnya dalam skala rasio/interval. Pengaruh variabel bebas dalam MCA dapat dinyatakan dalam bentuk nilai mean keseluruhan variabel bebas setelah mengontrol variable lain sehingga adjusted mean dapat dihitung dan lebih mudah diinterpratasikan dibanding koefisien yang dihasilkan melalui analisis regresi yang menggunakan dummy variabel [2].

Pada MCA, antar variabel dependen tidak boleh terdapat interaksi dan variabel dependen tidak memiliki nilai yang terlalu ekstrim (outlier). Data dengan outlier akan memengaruhi rata-rata dan varians sehinga memperngaruhi model yang terbentuk. Bila data terlalu ekstrim, maka diatasi dengan membuang observasi yang outlier atau melakukan transformasi [5]. Model yang digunakan dalam MCA adalah model aditif sebagai berikut.

$Y i j \ldots m=\bar{Y}+a i+b j+\cdots+\varepsilon i j \ldots m$

Di mana $\bar{Y}=\frac{\sum_{k=1}^{n} Y_{k}}{n}$

Keterangan:

$Y_{i j \ldots m}=$ skor pengamatan individu pada kategori ke-i dari variabel a, kategori ke-j dari variabel b, dst

$\bar{Y}=$ rata- rata keseluruhan variabel dependen

$a_{i}=$ pengaruh rata-rata keseluruhan kategori kei dari variable ke-a

$b_{j}=$ pengaruh rata-rata keseluruhan kategori kej dari variable ke-b

$\varepsilon_{i j \ldots m}=$ residual yang bersesuaian dengan $Y_{i j \ldots m}$

$Y_{k}=$ nilai individu ke-k pada variable dependen $n=$ jumlah observasi

Langkah-langkah yang dilakukan untuk mengetahui variabel kelompok pendapatan dan variabel jenis iklim negara tropis atau tidak yang mempengaruhi jumlah positif kasus COVID - 19 adalah sebagai berikut :

a. Melakukan observasi/pengamatan apakah distribusi variabel jumlah positif kasus COVID - 19 memiliki nilai ekstrim atau tidak. Selain itu juga untuk melihat sebaran data variabel bebasnya terdapat outlier atau tidak.

b. Melakukan pengujian model yaitu uji simultan dan uji parsial menggunakan uji ANOVA. Uji simultan maupun parsial digunakan untuk mengetahui apakah ada pengaruh variabel kelompok pendapatan dan variabel jenis negara tropis atau tidak terhadap variabel jumlah positif kasus COVID - 19 . Pengujian ini dilakukan dengan menguji nilai $\mathrm{F}$ main effect.

\section{Langkah - langkah uji ANOVA}

1. Menguji nilai $F$ main effect untuk mengetahui pengaruh variabel bebas terhadap variabel tak bebas dengan hipotesis: Ho: Tidak terdapat pengaruh antara variabel bebas terhadap variabel tak bebas 
H1: Terdapat pengaruh antara variabel bebas terhadap variabel tak bebas

2. Uji Simultan

Statistik uji yang digunakan adalah uji $\mathrm{F}$, yaitu:

$F=\frac{E /(C-P)}{T-E /(N-C+P-1)} \sim F_{(C-P) ;(N-C+P-1)}$

Keterangan :

$\mathrm{F}=$ Nilai $\mathrm{F}$ secara simultan

$\mathrm{E}=$ Explained sum squares kuadrat

$\mathrm{N}=$ Jumlah sampel

$\mathrm{C}=$ Jumlah kategori variable independen

$\mathrm{P}=$ Jumlah variabel independen

$\mathrm{T}=$ Total sum of squares

Keputusan: Tolak Ho jika $p$-value $<\alpha$ (tingkat signifikansi) atau $\mathrm{F}>$ $F_{(C-P) ;(N-C+P-1)}$.

c. Melakukan pengecekan ada atau tidaknya interaksi antar variabel bebasnya. Karena model bersifat aditif, maka harus dipastikan bahwa nilai suatu variabel bebas tidak dipengaruhi nilai variabel bebas lainnya. Untuk itu dilakukan uji signifikasi F pada pola interaksi antar variabel bebas yang terbentuk.

Menguji interaksi antar variabel bebas:

Ho: Tidak terdapat interaksi antar variabel bebas $H 1$ : Terdapat interaksi antar variabel bebas

Ada tiga tahap yang perlu dilakukan untuk menguji adanya interaksi [6].

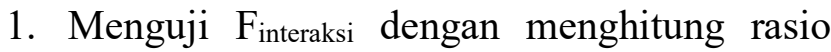
antara mean square interaksi antar variabel bebas dan mean square residual. Tolak $\mathrm{Ho}$ jika p-value $<\alpha$ atau $\left.\mathrm{F}>F_{(C-P) ;(N-C+P-1)}\right)$. Jika p-value $<5 \%$, hal ini berarti (pengujian dilanjutkan pada tahap ke-2). Jika p-value $\geq$ $5 \%$, hal ini berarti tidak ada interaksi antara variabel bebas (pengujian asumsi cukup sampai di sini).

2. Menghitung rasio antara sum of square interaksi variabel bebas dan sum of square dari main effect. Jika hasil rasio $>10 \%$, hal ini berarti terdapat interaksi yang tidak bisa diabaikan (pengujian dilajutkan pada tahap ketiga). Jika hasil rasio $\leq 10 \%$, hal ini berarti interaksi antara variabel bebas dapat diabaikan (pengujian asumsi berhenti).
3. Menghitung rasio antara sum of square interaksi variabel bebas dan sum of square total. Jika rasio $>1 \%$, berarti terdapat interaksi dan analisis dengan menggunakan MCA tidak dapat dilakukan. Jika rasio $\leq 1 \%$, berarti interaksi boleh diabaikan atau dapat dikatakan interaksi benar-benar tidak ada dan asumsi model aditif dapat terpenuhi.Menghitung nilai eta $(\eta)$ dan beta ( $\beta)$ untuk mengetahui seberapa besar pengaruh yang diberikan masing-masing variabel bebas terhadap variabel tak bebas. Nilai eta digunakan untuk mengukur hubungan masing - masing variabel bebas terhadap variabel tak bebas sebelum mempertimbangkan pengaruh dari variabel bebas lainnya, sedangkan nilai beta digunakan untuk mengukur hubungan masing - masing variabel bebas terhadap variabel tak bebas setelah mempertimbangkan pengaruh dari variabel bebas lainnya.

Statistik Eta $(\eta)$

$$
\begin{aligned}
\eta_{i} & =\sqrt{\frac{U_{i}}{T}} \\
U_{i} & =\sum_{i}\left(\sum_{j} W_{i j k}\right)\left(\bar{y}_{i j}-\bar{y}\right)^{2} \\
T & =\sum_{k} W_{k}\left(y_{k}-\bar{y}\right)^{2}
\end{aligned}
$$

Keterangan :

$\eta_{i}=$ Nilai eta untuk variabel $\mathrm{ke}-\mathrm{i}$

Statistik Beta $(\beta)[6]$

$$
\begin{aligned}
& \beta_{i}=\sqrt{\frac{D_{i}}{T}} D_{i} \\
& =\sum_{i}\left(\sum_{j} W_{i j k}\right)\left(a_{i j}\right)^{2}
\end{aligned}
$$

Keterangan :

$\beta_{i}=$ nilai beta untuk variabel $\mathrm{ke}-\mathrm{i}$

$a_{i j}=$ Deviasi variabel bebas ke $-\mathrm{I}$ kategori $\mathrm{j}$ yang disesuaikan

$\mathrm{N}=$ Jumlah sampel

$\mathrm{C}=$ Jumlah kategori variable independen

$\mathrm{P}=$ Jumlah variabel independen

Selain itu, untuk melihat seberapa besar variabel kelompok pendapatan dan variabel jenis 
negara tropis secara bersama sama dapat menjelaskan variabel jumlah positif kasus COVID - 19, dapat digunakan koefisien determinasi $\left(\mathrm{R}^{2}\right)$ yang dapat dilihat pada persamaan $(0.5)$.

$$
\begin{aligned}
& R^{2}=E / T \\
& R^{2}{ }_{a d j}=1-\left[\frac{(T-E) /(N-C+p-1)}{T /(N-1)}\right]
\end{aligned}
$$

Keterangan :

$\mathrm{E}=$ Explained sum squares kuadrat

$\mathrm{T}=$ Total sum of squares

\section{METODOLOGI}

\section{Variabel Penelitian}

Variabel tidak bebas dalam penelitian ini adalah jumlah kasus positif COVID - 19 . Sedangkan variabel bebasnya adalah kelompok pendapatan dan kelompok negara tropis atau bukan tropis. Penelitian ini menggunakan unit observasi seluruh negara yang mengalami kasus positif COVID - 19.

\begin{tabular}{|c|c|c|c|}
\hline Variabel & Nama & Kategori & Kode \\
\hline (1) & (2) & (3) & (4) \\
\hline $\mathrm{Y}$ & $\begin{array}{l}\text { Jumlah Kasus } \\
\text { Positif COVID - } \\
19 \text { di Benua Asia }\end{array}$ & $\begin{array}{l}\text { (satuan } \\
\text { jumlah) }\end{array}$ & - \\
\hline $\mathrm{X}_{1}$ & $\begin{array}{l}\text { Kelompok } \\
\text { Pendapatan }\end{array}$ & $\begin{array}{l}\text { Low } \\
\text { Middle - } \\
\text { Low } \\
\text { Middle - } \\
\text { Upper } \\
\text { High }\end{array}$ & $\begin{array}{l}1 \\
2 \\
3 \\
4\end{array}$ \\
\hline $\mathrm{X}_{2}$ & Negara Tropis & $\begin{array}{l}\text { Ya } \\
\text { Tidak }\end{array}$ & $\begin{array}{l}1 \\
2\end{array}$ \\
\hline
\end{tabular}

Tabel 1. Rincian Variabel Penelitian

\section{Sumber Data}

Sumber data yang digunakan dalam penelitian ini adalah sebagai berikut.

Tabel 2. Sumber Data Variabel Penelitian

\begin{tabular}{c|l|l}
\hline Variabel & \multicolumn{1}{|c|}{ Nama } & \multicolumn{1}{|c}{ Sumber } \\
\hline$(1)$ & \multicolumn{1}{|c}{$(2)$} & \multicolumn{1}{|c}{$(3)$} \\
\hline \multirow{3}{*}{$\mathrm{Y}$} & Jumlah Kasus Positif & Situs \\
& COVID -19 di Benua & Worldometers \\
& Asia & (11 April 2020) \\
$\mathrm{X}_{1}$ & Kelompok & Situs \\
& Pendapatan & HungerMap
\end{tabular}

\begin{tabular}{c|c|c}
\hline Variabel & Nama & Sumber \\
\hline$(1)$ & $(2)$ & $(3)$ \\
\hline $\mathrm{X}_{2}$ & Negara Tropis & Profil Negara \\
\hline
\end{tabular}

\section{PEMBAHASAN}

Untuk mengawali penelitian ini, dilakukan pemeriksaan terlebih dahulu terhadap distribusi data variabel jumlah kasus positif COVID-19 di negara-negara Benua Asia sebagai variabel prediktor dalam penelitian ini. Hasilnya adalah sebagai berikut.

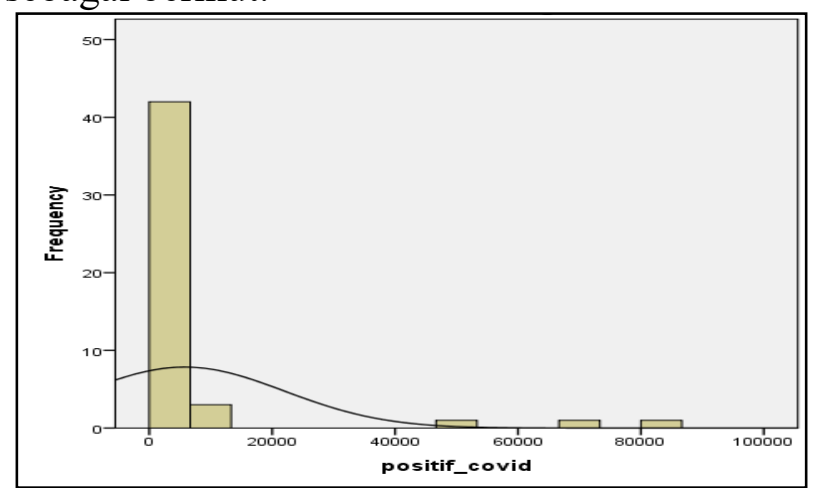

Grafik 1. Distribusi Data Jumlah Kasus Positif COVID-19 di Negara-negara Benua Asia (sebelum transformasi)

Pada Grafik 1, dapat diketahui bahwa distribusi data tidak simetris. Maka perlu dilakukan transformasi terhadap data tersebut. Dalam penelitian ini, data ditransformasi dengan menggunakan transformasi $\ln$. Setelah dilakukan transformasi, distribusi data menjadi simetris sehingga dapat dilanjut ke tahap analisis selanjutnya. Data setelah ditransformasi ditampulkan sebagai berikut.

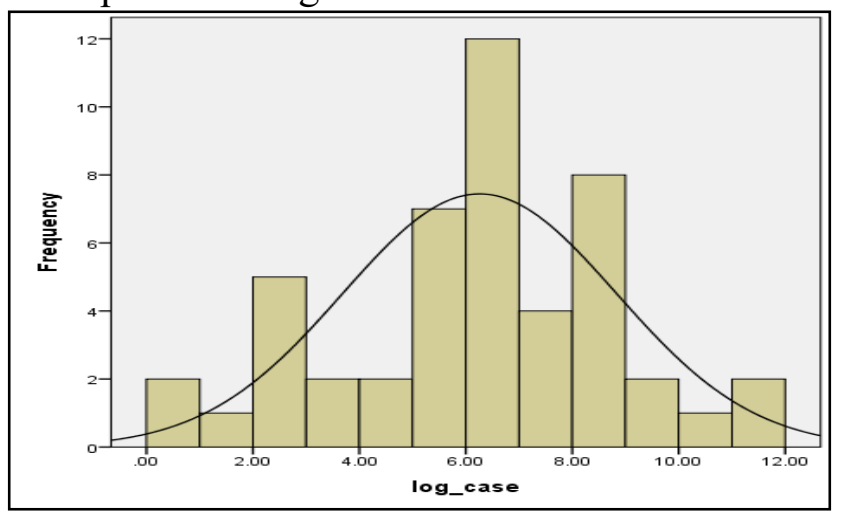

Grafik 2. Distribusi Data Jumlah Kasus Positif COVID-19 di Negara-negara Benua Asia (setelah transformasi) 
Setelah memastikan data tersebar secara simetris, analisis dilanjutkan dengan melakukan pengujian main effect dari variabel kelompok pendapatan dan variabel negara tropis terhadap variabel kasus positif COVID-19 negara-negara di Benua Asia. Pengujian dilakukan dengan menggunakan Uji ANOVA. Hasilnya adalah sebagai berikut.

\begin{tabular}{l|c|c|c|c|c}
\multicolumn{7}{c}{ Tabel 2. Uji ANOVA } \\
\hline & SS & df & $\begin{array}{c}\text { Mean } \\
\text { Square }\end{array}$ & F & Sig. \\
\hline (Combined) & 102,571 & 4 & 25,643 & 5,287 & 0,001 \\
income & 96,441 & 3 & 32,147 & 6,628 & 0,001 \\
tropic & 13,936 & 1 & 13,936 & 2,873 & 0,097 \\
Model & 102,571 & 4 & 25,643 & 5,287 & 0,001 \\
Residual & 208,556 & 43 & 4,850 & & \\
Total & 311,127 & 47 & 6,620 & & \\
\hline
\end{tabular}

Hasil uji ANOVA (Tabel 2) menunjukkan nilai $p$-value model sebesar 0,001 . Artinya, dengan tingkat signifikansi 10 persen terdapat cukup bukti untuk menyatakan bahwa terdapat minimal satu variabel bebas yang signifikan mempengaruhi jumlah kasus positif COVID-19 negara-negara di Benua Asia. Kemudian, nilai $p$-value $=0,001$ yang ditunjukkan pada combined menunjukkan bahwa dengan tingkat signifikansi 10 persen terdapat cukup bukti untuk menyatakan bahwa variabel kelompok pendapatan dan variabel negara tropis mempengaruhi jumlah kasus positif COVID-19 negara-negara di Benua Asia secara simultan. Selain mempengaruhi secara simultan, masing-masing variabel variabel kelompok pendapatan dan variabel negara tropis juga mempengaruhi secara parsial. Hal ini ditunjukkan oleh nilai $p$-value masing-masing yaitu sebesar 0,001 dan 0,097.

Setelah melakukan uji main effect, tahapan analisis dilanjutkan dengan menguji interaksi antar variabel bebas yang dalam penelitian ini adalah variabel kelompok pendapatan dan variabel negara tropis. Hasil pengujian ditunjukkan dalam tabel berikut.

Tabel 3. Uji Interaksi

\begin{tabular}{|c|c|c|c|c|}
\hline SS & SS & df & $\begin{array}{c}\text { Mean } \\
\text { Square }\end{array}$ & Sig. \\
\hline income * tropic & 5,491 & 2 & 2,746 &, 554 \\
\hline
\end{tabular}

Berdasarkan hasil uji interaksi dua arah di atas, dengan tingkat signifikansi 10\% belum terdapat cukup bukti untuk menyatakan bahwa variabel kelompok pendapatan dan variabel negara tropis memiliki interaksi, sehingga dapat disimpulkan bahwa tidak ada interaksi signifikan di antara kedua variabel bebas dalam penelitian ini. Hasil ini mengindikasikan analisis MCA dapat dilanjutkan ke tahap berikutnya. Dengan begini, tidak perlu dilakukan uji interaksi menggunakan rasio jumlah kuadrat interaksi dengan main effect maupun rasio jumlah kuadrat interaksi dengan jumlah kuadrat total.

Setelah seluruh uji telah terpenuhi, dilanjutkan dengan analisis pola hubungan antara variabel kelompok pendapatan dan variabel negara tropis dengan jumlah kasus positif COVID-19 negara-negara di Benua Asia. Hasilnya dapat dilihat di tabel berikut.

Tabel 4. Analisis MCA

\begin{tabular}{c|c|c|c|c|c}
\hline \multirow{2}{*}{\multicolumn{2}{c|}{}} & \multicolumn{2}{|c}{ Predicted Mean } & \multicolumn{2}{c}{ Deviation } \\
\cline { 3 - 6 } \multicolumn{2}{c}{} & Unadj. & Adj. & Unadj. & Adj. \\
\hline Kelom & Low & 2,8494 & 2,4234 & $-3,4089$ & $-3,8349$ \\
pok & Low-Mid & 5,2829 & 5,4182 & $-0,9754$ & $-0,8401$ \\
pendap & Up-Mid & 7,3434 & 7,5188 & 1,0851 & 1,2605 \\
atan & High & 7,1300 & 6,9445 & 0,8717 & 0,6862 \\
Negara & Ya & 5,7757 & 5,4815 & $-0,4826$ & $-0,7768$ \\
tropis & Tidak & 6,5229 & 6,6843 & 0,2646 & 0,4260 \\
\hline
\end{tabular}

Dari output di atas, dapat dibentuk model sebagai berikut:

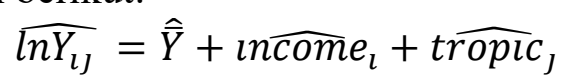

Nilai $\hat{Y}$ (grand mean) diperoleh dari nilai rata-rata jumlah kasus positif COVID-19 pada negara-negara di Benua Asia. Sedangkan koefisien model diperoleh dari nilai adjusted deviation pada Tabel 4. Karena pada awal analisis telah dilakukan transformasi ln pada data, maka untuk melakukan estimasi jumlah kasus positif COVID-19 harus dilakukan transformasi kembali dengan rumus:

$$
\widehat{Y_{l \jmath}}=e^{\widehat{\operatorname{nY_{l\jmath }}}}=\exp \left(\widehat{\ln Y_{l \jmath}}\right)
$$

Dari model yang terbentuk dan telah ditransformasi kembali di atas, estimasi jumlah kasus positif COVID-19 pada negara-negara di Asia berdasarkan negara tropis/non-tropis dan kelompok pendapatan adalah sebagai berikut:

Tabel 5. Hasil Estimasi Model MCA 


\begin{tabular}{c|l|c|c}
\hline $\begin{array}{c}\text { Negara } \\
\text { Tropis/ } \\
\text { Non- } \\
\text { tropis }\end{array}$ & $\begin{array}{c}\text { Kelompok } \\
\text { Pendapatan }\end{array}$ & $\widehat{\operatorname{lnY}}$ & $\widehat{Y_{l \jmath}}$ \\
\hline$(1)$ & \multicolumn{1}{|c|}{$(2)$} & $(3)$ & \multicolumn{1}{c}{$(4)$} \\
\hline \multirow{5}{*}{ Tropis } & Rendah & 1,6466 & 5,1893 \\
& Menengah bawah & 4,6415 & 103,6946 \\
& Menengah atas & 6,7420 & 847,2620 \\
& Tinggi & 6,1678 & 477,1114 \\
Non- & Rendah & 2,8494 & 17,767 \\
Tropis & Menengah bawah & 5,8442 & 345,2332 \\
& Menengah atas & 7,9448 & 2820,8118 \\
& Tinggi & 7,3705 & 1588,4596 \\
\hline
\end{tabular}

Hasil estimasi pada kolom (4) tabel di atas menunjukkan bahwa kasus positif COVID19 di Benua Asia lebih banyak terjadi di negara nontropis dibandingkan negara tropis. Berdasarkan kelompok pendapatan, semakin tinggi kelompok pendapatan pada negara tropis di Benua Asia maka jumlah kasus positif COVID19 diperkirakan akan cenderung meningkat. Begitu juga pada negara non-tropis. Sementara itu, kasus tertinggi diperkirakan banyak terjadi di negara non-tropis dengan kelas pendapatan menengah ke atas.

Setelah estimasi model, tahap berikutnya adalah menentukan variabel yang paling berpengaruh terhadap jumlah kasus positif COVID-19 pada negara-negara di Benua Asia di antara variabel bebas dalam penelitian yang dapat dilihat melalui nilai eta dan beta dalam tabel berikut.

Tabel 6. Nilai Eta dan Beta

\begin{tabular}{c|c|c}
\hline Variabel & Eta & Beta \\
\hline income & 0,534 & 0,563 \\
tropic & 0,140 & 0,226 \\
\hline
\end{tabular}

Dari tabel di atas, diketahui bahwa dalam penelitian ini variabel kelompok pendapatan merupakan variabel yang paling mempengaruhi jumlah kasus positif COVID19 pada negaranegara di Benua Asia. Hal ini dapat dilihat dari nilai beta yang lebih besar dibandingkan nilai beta variabel negara tropis.

Untuk mengetahui besar proporsi varians jumlah kasus positif COVID-19 pada negaranegara di Benua Asia, dilakukan goodness of fit. Nilai $\mathrm{R}^{2}$ yang dihasilkan adalah sebesar 0,330 . Artinya variabel kelompok pendapatan dan variabel negara tropis secara bersama-sama dapat menjelaskan variasi jumlah kasus positif COVID-19 pada negara-negara di Benua Asia sebesar 33\% dan sisanya sebesar $67 \%$ dijelaskan oleh variabel lain yang tidak terdapat dalam model.

\section{KESIMPULAN}

Berdasarkan hasil analisis yang telah dijabarkan, kesimpulan yang diperoleh yaitu bahwa kelompok pendapatan lebih mempengaruhi jumlah kasus positif COVID-19 dibandingkan apakah negara itu merupakan negara tropis atau bukan. Akan tetapi bila ditelusuri secara lebih rinci, kasus positif COVID-19 di Benua Asia lebih banyak terjadi di negara non-tropis dibandingkan negara tropis. Sedangkan berdasarkan kelompok pendapatan, semakin tinggi kelompok pendapatan pada negara tropis di Benua Asia maka jumlah kasus positif COVID-19 diperkirakan cenderung lebih tinggi dibandingkan jumlah kasus positf pada kelompok pendapatan yang lebih rendah. Begitu juga pada negara non-tropis.

Nilai proporsi varians yang dapat dijelaskan oleh model yang diperoleh tidak cukup besar, yaitu hanya 33\%. Hal ini dikarenakan variabel bebas yang diteliti merupakan variabel kategorik yang tidak begitu kuat untuk menjelaskan variasi variabel berskala interval atau rasio. Di samping itu, masih banyak faktor lain yang dapat mempengaruhi jumlah kasus COVID-19 pada negara-negara di Benua Asia, sehingga tidak semuanya berhasil tercakup dalam penelitian ini.

\section{DAFTAR PUSTAKA}

[1] Arcana, I.M. (2016). Penerapan Multiple Classification Analysis (MCA) Dalam Penentuan Upah Minumum Provinsi (UMP) Indonesia. Sambutan Ketua Panitia. Sekolah Tinggi Ilmu Statistik (STIS).

[2] Firdaus, A., et al. (2019). Penentuan Garis Kemiskinan Provinsi Menggunakan Metode Multiple Classification Analysis (MCA). Buletin Ilmiah Matematika Statistika dan Terapannya (Bimaster). 8(4), 789-798.

[3] HungerMap (2020). COVID-19 Statistics by Country Income Group [diakses 11 April 
2020]. Tersedia dari: https://hungermap.wfp.org/.

[4] Njotoprajitno, R.S. (2010). Aplikasi Multiple Classification Analysis Dalam Penentuan Faktor Yang Mempengaruhi Gaji Dosen. Jurnal Managemen Maranatha, $9(2), 63-84$.

[5] Sugiarto (2018). Multiple Classification Analysis (MCA) Sebagai Metode Alternatif Analisis Data untuk Variabel Bebas yang Kategori. Jurnal Statistika Universitas Muhammadiyah Semarang, 6(2), 85-93.

[6] Susel, A. (2011). Multiple Classification Analysis: Theory and Aplication to Demography. Journal of Acta Universitatis Lodziensis. 255, 183-189.

[7] Worldometers. (2020). COVID-19 Coronavirus Pandemic [diakses 11 April 2020]. Tersedia dari: worldometers.info/coronavirus/. 